\title{
Gadget and adolescent: Its effect depiction on daily life
}

\author{
Roni Herdianto ${ }^{\mathrm{a}, 1, *}$, Dzikra Syahidin ${ }^{\mathrm{b}, 2}$ \\ ${ }^{a}$ Postgraduate, Universitas Negeri Malang, Malang, Indonesia \\ b SMPIT Al-Hikmah, Blitar, Indonesia \\ ${ }^{1}$ roni.herdianto@um.ac.id*; ${ }^{2}$ syahidindzikra@gmail.com \\ * corresponding author
}

\author{
ARTICLE INFO ABSTRACT
}

Article history

Received June 13, 2020

Revised July 1, 2020

Accepted July 28, 2020

Keywords

gadget user

adolescence

social-religious aspect

\begin{abstract}
Adolescence and gadget are inseparable these days. This research aimed at describing the characteristics of gadget user and social-religious aspect influence. This research employed descriptive qualitative method. The researchers took a role as an observer dan data collector. This research was conducted on Junior High School X. It took 39 male students as the subject. The data collection was done by distributing the questionnaire. The questionnaire consisted of 14 items. The data obtained were arranged based on the discussion category. The findings explained: (1) the characteristics of adolescences in Junior High School X as the gadget user, gadget ownership characteristics, usage duration, how to obtain internet access, internet use, the most used application; (2) the influence of gadget use on the social life such as pornographic content, social interaction, studying concentration, and religious aspect of the adolescence. This research concludes that, based on the characteristics of the users, gadget provides both negative and positive impact. Furthermore, it is crucial to have attention and guidance by the related stakeholders to be concerned about the mental health of the adolescence as well as the social-religious aspects.
\end{abstract}

This is an open access article under the CC-BY-SA license.

\section{Introduction}

The recent development of information and telecommunication technology these days has promoted a radical and wide-ranging adjustment of human social life. One of the notable developments of information and communication technology is a development of internet and gadget. These days, it is mainstream for young adulthood or adolescence to have their own gadgets such as smartwatch, smartphone, tablet, virtual reality-augmented reality device, wearable android device, and so forth. Nowadays, the young adulthood and adolescence, commonly called millennial generation, are inseparable from any gadget in their daily life [1]-[3]. Such phenomena also occurs among Indonesian young adulthood; they seem unable to live without their gadget [2], [4], [5].

Indonesian Association for Internet Service Providers reported that around 64.8\% of Indonesians are active internet user [4]. Information and Communication Ministry has revealed that the internet users in Indonesia reached 63 million people and a number of $95 \%$ used internet connection to access social media [2]. Furthermore, from a number of 63 million, $80 \%$ of the internet users are the young adulthood; to access educational content, entertainment, online shopping, social media and so forth [2], [6]. Among the diverse types of gadget, smartphone is the most preferable gadget due to its practicality and convenience [2], [4].

During its development, internet connection does not only aim at supporting educational or learning processes as well as trading activities. Into the bargain, internet connection plays a role as a primary channel of communication which we commonly refer to social media. When using internet, young adulthood mostly accesses social media. At that point in time, Facebook is the most used social media followed by Instagram, WhatsApp, Twitter, and so forth [2], [4]. 
A more targeted and specific search for news on Google by entering the keyword "teenager internet" found around 48,900 results and most of it was news about the use of the internet by teens around the world that was positive and negative. Examples of positive news related to internet are to use internet for communicating, seeking information, and educational purposes. While examples of negative news are about pornography, hacking, wiretapping, drug transactions, terrorism, fraud and so forth. If the keyword typed "teenagers' social media", it found 18,200 results. The results were mostly dominated by the impacts of the use of social media on adolescents, both negative and positive.

Some examples of the social impact of using gadgets are as follows. Research conducted by Lestari mentioned the use of gadgets to influence patterns of social interaction in the family as a whole [3]. Research on adolescents in Russia and Germany explained that interference due to playing games on the internet had been shown to reduce adolescent mental health [7], [8]. The last example was a study conducted by several researchers in the UAE and Indonesia and concluded the negative impact of gadget addiction. The research revealed that children tend to be individualistic, difficult to get along with, difficult to control the use of gadgets and consequently, it obstructs the development of the brain [9], [10].

Preliminary studies conducted by researchers revealed that the adolescents used as the object of research were $84.6 \%$ having personal gadgets; $53.8 \%$ of them own gadgets over 2 years; $51.3 \%$ of them using gadgets for 1-5 hours/day; 59\% get internet access by using Wi-Fi.

This research is important because it is a common problem throughout the world regarding teenagers. The information obtained from the results of the study is used as a reference for handling the next step, especially in anticipating the negative impact of the use of gadgets by adolescents in their daily lives. Although there have been many articles that discuss the effect of gadgets on adolescent social life, in particular there have not been many articles that describe the impact of the use of gadgets in adolescent social-religious life based on religious views.

This study aims to describe the characteristics of gadget users and the impact of using gadgets on the social-religious life of adolescent at X Junior High School in their daily lives.

\section{Method}

This research employed a qualitative research design and used a descriptive approach that aimed at describing and interpreting the object of the study according to the obtained fact in the field. This research aimed at depicting the impact of gadget use on the social life of adolescences at Junior High School X in detail [11].

During this research, the researchers took a role as an observer and data and information collector from the respondents. This research was conducted at Junior High School X. The data collection was conducted between $9^{\text {th }}$ until $10^{\text {th }}$ October 2019 around 09.30-10.00 Indonesian Western Standard Time (UTC+07.00). The data were collected through a descriptive questionnaire. To obtain a more comprehensive findings, this research used a descriptive questionnaire that enables the presence of the researchers during the interview. The data were collected directly from the distribution of questionnaire to the subject of the research. It tools 39 male adolescences of Junior High School X. The questionnaire consisted of 14 items. The items given were related to the user profile in using internet, the use of internet, pornographic content access, social relation with other gender and parents, its effect on the learning concentration and Quran recitation, children responses on Adzan (prayer calling), as well as the frequency and convenience of interactions with gadgets when compared to direct social interactions

The obtained data were then arranged according to the category of findings in the discussion part. The results and discussions obtained have a systematic arrangement and are related to one another. A conclusion is drawn up after a comprehensive discussion has been made.

\section{Results}

Based on the data collection that has been done, it obtained answers from 39 respondents (21 respondents in class $8 \mathrm{~B}$ and 18 respondents in class $8 \mathrm{C}$ ) to the 14 questions given. 
The results of recapitulation of answers to questions about gadget ownership by 39 respondents is presented in Fig. 1.

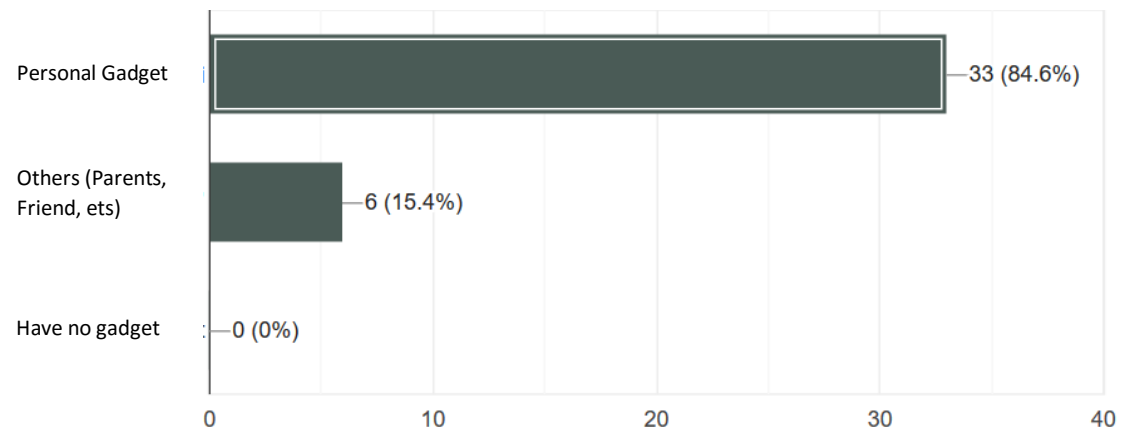

Fig. 1.Question 1 Recapitulation Results

Fig. 1 shows that private ownership of gadget among adolescence at Junior High School X ranks the highest; amounted to 33 or $84.6 \%$. The rest of the respondents do not own the gadget by themselves. Then, the following Fig. 2 illustrates how long they own the gadget from the 39 research subjects.

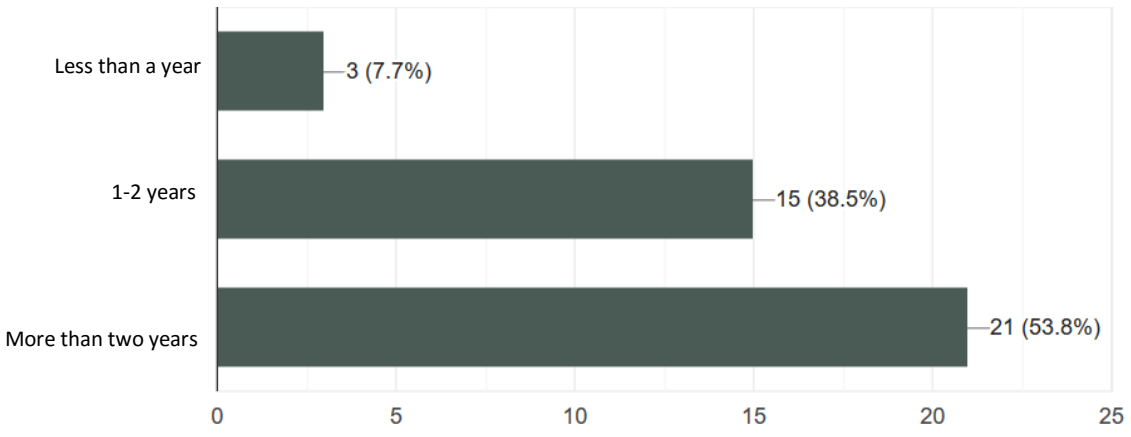

Fig. 2.Question 2 Recapitulation Results

Fig. 2 illustrates that most adolescences at Junior High School X own gadget more than 2 years. The number was 21 or $53.8 \%$. Meanwhile, only three adolescences at Junior High School X own gadget less than a year $(7.7 \%)$. Then, the following Fig. 3 depicts the duration of gadget use in the daily life by the 39 research subjects.

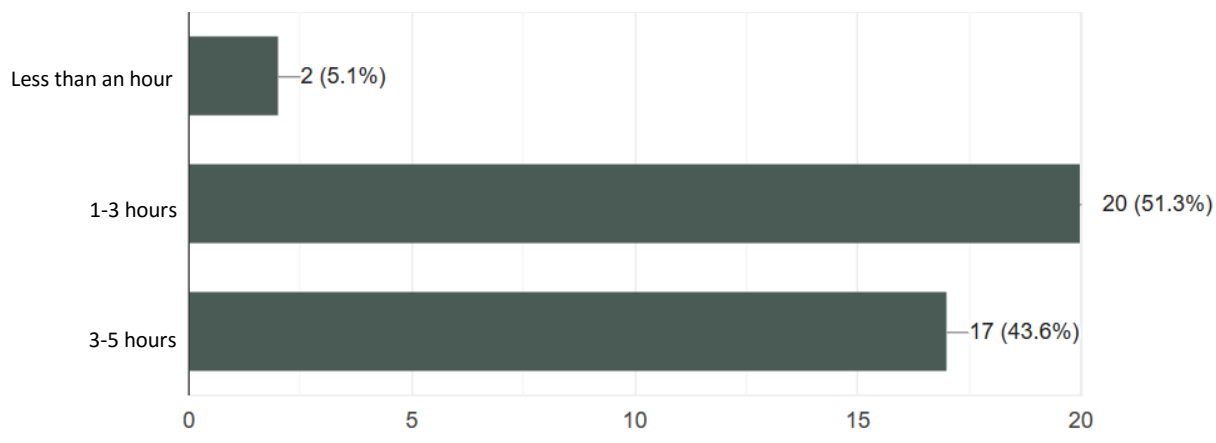

Fig. 3.Question 3 Recapitulation Results

Fig. 3 illustrates that most adolescences at Junior High School $\mathrm{X}$ use gadget from three to five hours a day. The number was 17 or $43.6 \%$. Meanwhile, only two adolescences at Junior High School X use gadget less than an hour (5.1\%). Then, the following Fig. 4 depicts how the 39 research subjects were connected to the internet. 


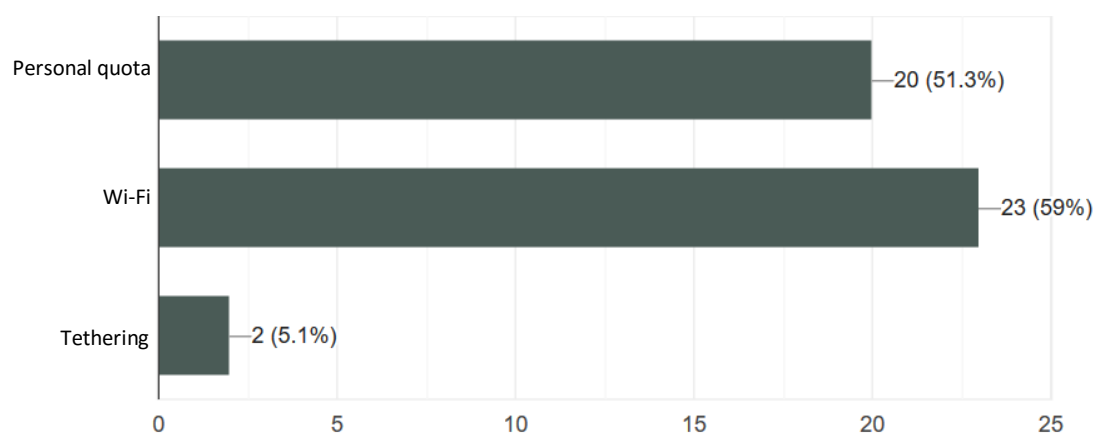

Fig. 4.Question 4 Recapitulation Results

Based on Fig. 4, it shows that the connection access acquired by the adolescence at Junior High School X. Amounted to 23 or 59\% adolescences at Junior High School used Wi-Fi connection. The least number was two adolescences who acquired internet connection from peer-tethering connection (5.1). Then, the following Fig. 5 illustrates how they use their own the gadget from the 39 research subjects.

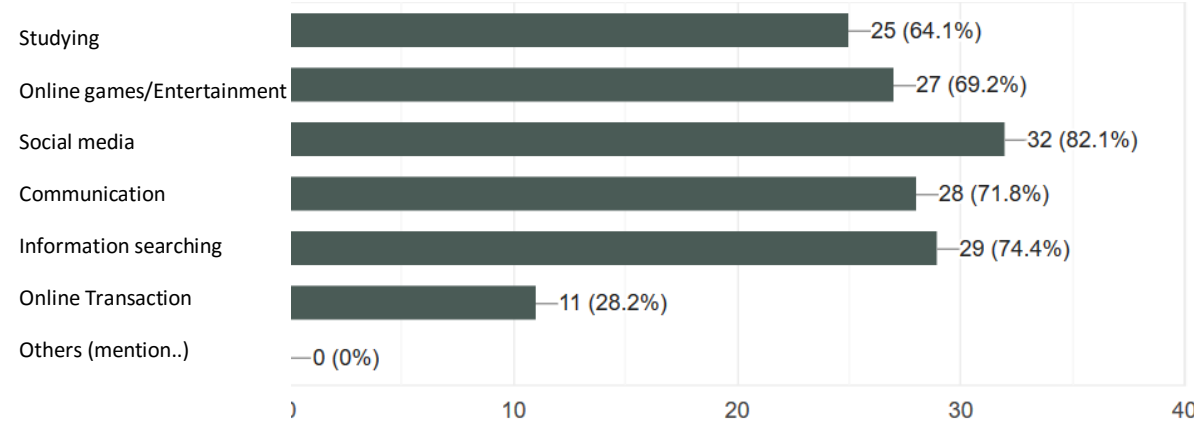

Fig. 5.Question 5 Recapitulation Results

Fig. 5 illustrates that most adolescences at Junior High School X use their gadget for accessing social media. The number was 32 or $82.1 \%$. Meanwhile, only 11 adolescences at Junior High School $\mathrm{X}$ use gadget for having an online transaction $(5.1 \%)$. Then, the following Fig. 6 depicts the social media that is accessed by the 39 research subjects.

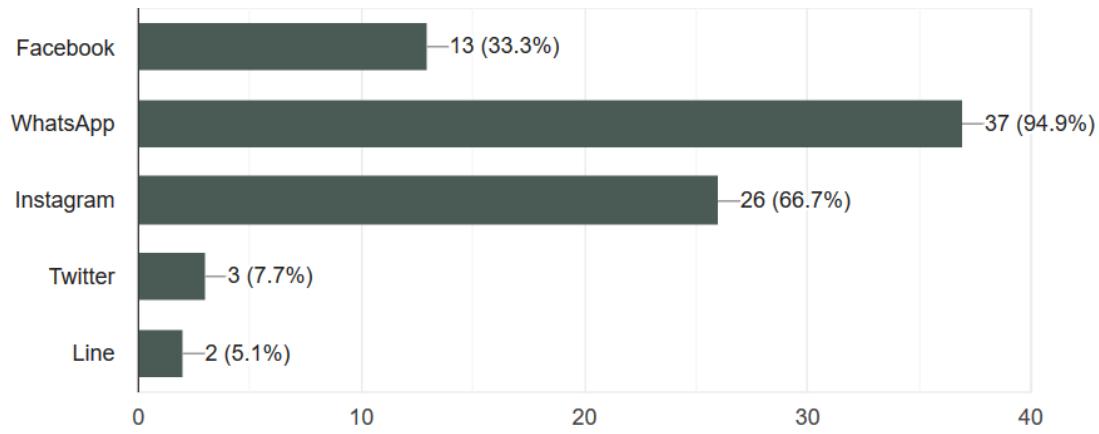

Fig. 6. Question 6 Recapitulation Results

Fig. 6 illustrates that most adolescences at Junior High School X use their gadget for accessing WhatsApp. The number was 37 or $94.9 \%$. Meanwhile, only two adolescences at Junior High School $\mathrm{X}$ use gadget for accessing Line (5.1\%). Then, the following Fig. 7 depicts the use of gadget on the learning concentration among the 39 research subjects. 


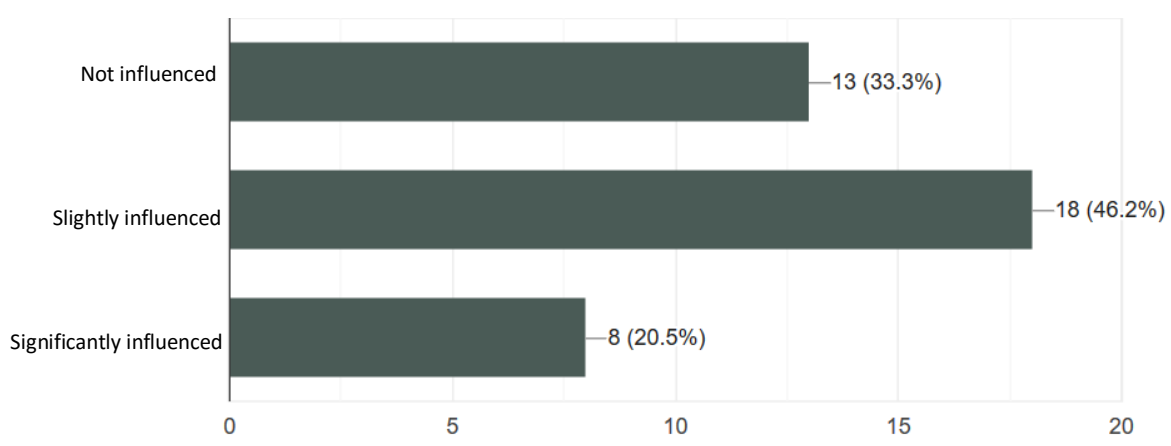

Fig. 7.Question 7 Recapitulation Results

According to Fig. 7, it illustrates that the concentration of studying of the subject at Junior High School X was slightly influenced using gadget. The number was 18 or $46.2 \%$. Meanwhile, only eight adolescences at Junior High School X confirmed that their concentration of studying was significantly influenced. Then, the following Fig. 8 depicts the frequency of accessing pornography content among the 39 research subjects.

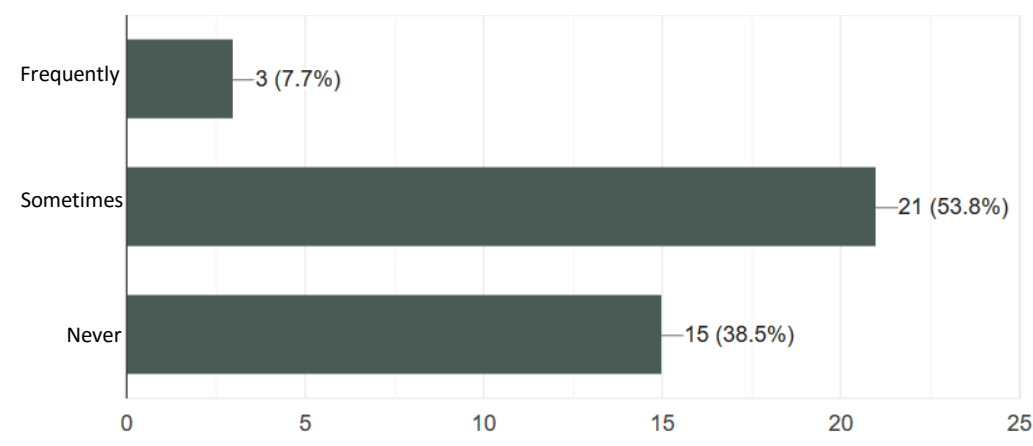

Fig. 8.Question 8 Recapitulation Results

According to Fig. 8, it illustrates that the frequency of accessing the pornography content by the subject at Junior High School X. Around 21 students seldom accessed the pornography content using internet $(53.8 \%)$. Only three students that had never been accessed the pornography content (7.7\%) Then, the following Fig. 9 depicts the frequency of using their gadget for contacting the other gender friends among the 39 research subjects.

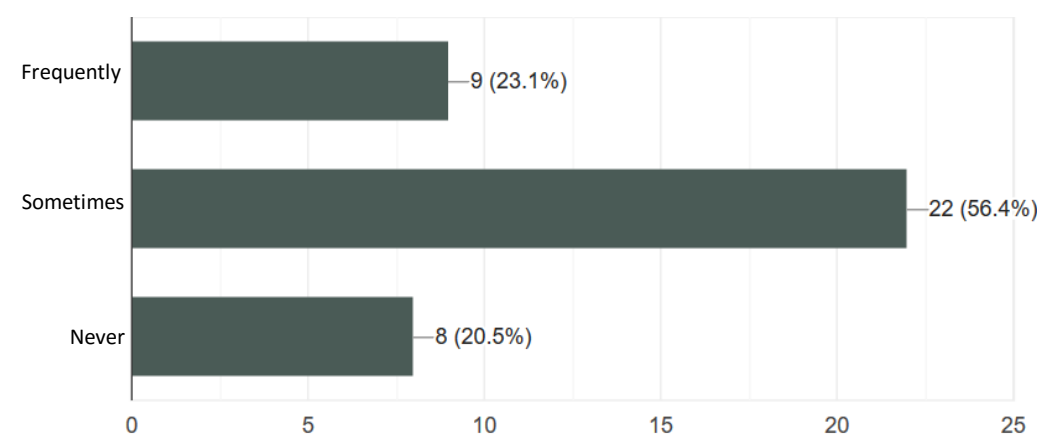

Fig. 9.Question 9 Recapitulation Results

Fig. 9 indicates that most of the subjects from Junior High School X seldom contacted their other gender friends by using their gadget. It was 22 subjects or $56.4 \%$. Meanwhile, eight subjects $(20.5 \%)$ confirmed that they have never contacted their other gender friends by using their gadget. 
Further, Fig. 10 illustrates the answer results from the 39 subjects regarding the question whether they were bothered when their parents or friends asked for a help when they were using their gadget.

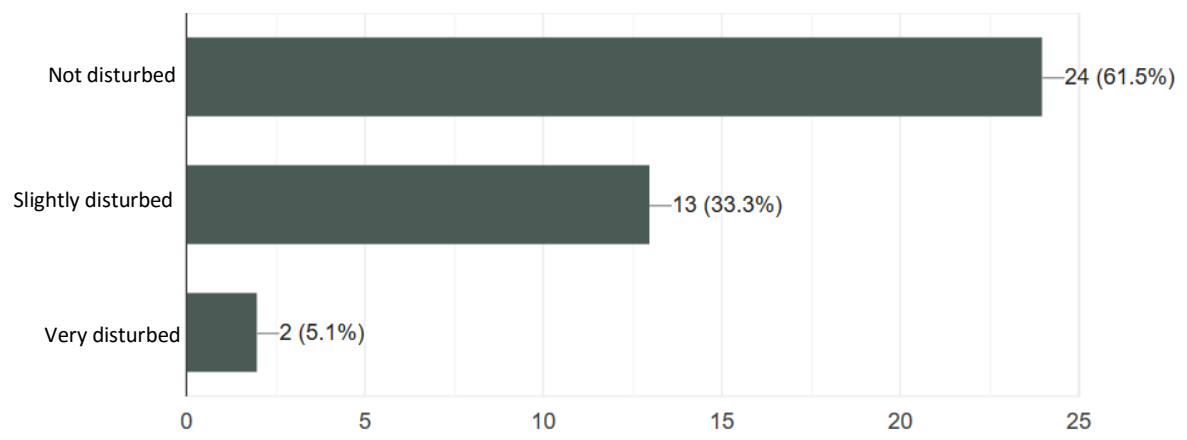

Fig. 10. Question 10 Recapitulation Results

Fig. 10 indicates that most of the subjects from Junior High School X were using their gadget. It was 22 subjects or $56.4 \%$. Meanwhile, eight subjects $(20.5 \%)$ confirmed that they have never contacted their other gender friends by using their gadget. Further, Fig. 11 illustrates the answer results from the 39 subjects when they were not using their gadget.

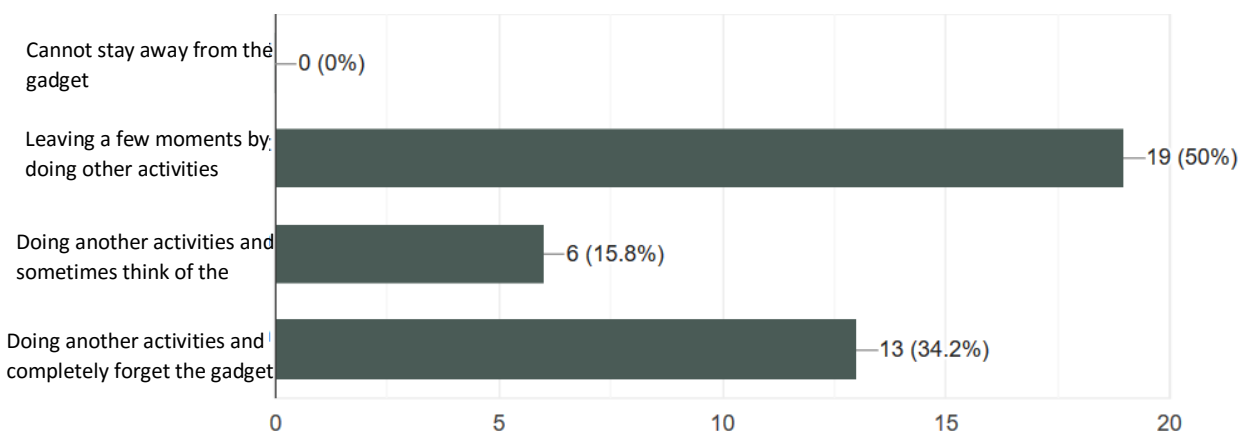

Fig. 11. The Question 11 Recapitulation Results

Fig. 11 above explains that the most subject did other activity(s) when they were not playing with their gadget. There were 19 adolescences at Junior High School X who answered or approximately $50 \%$. Meanwhile, there were six subjects that tend to think of their gadget while doing another activity $(15.8 \%)$.

The next question was "Which one do you prefer the best, playing gadget at your house or playing outside with your friends?". The answers provided by the 39 respondents are illustrated in the Fig. 12.

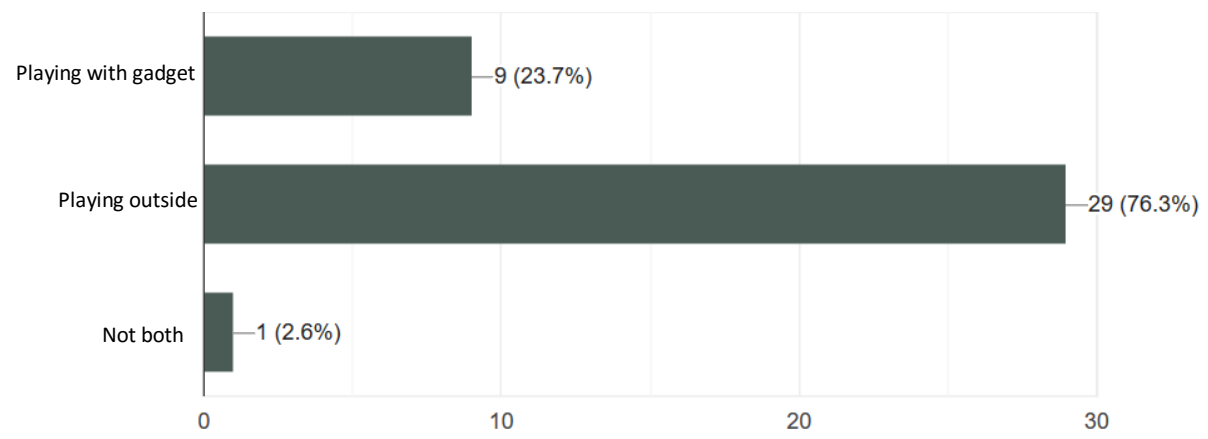

Fig. 12. The Question 12 Recapitulation Results 
Fig. 12, shows that the 29 subjects at Junior High School X chose to play outside with their friends rather than playing their gadget at the home (76.3\%). Meanwhile, only one subject did not chose both options (2.6\%). The following Fig. 13 illustrates the response of the subject when they listened to the Adzan (prayer calling) while playing their gadget.

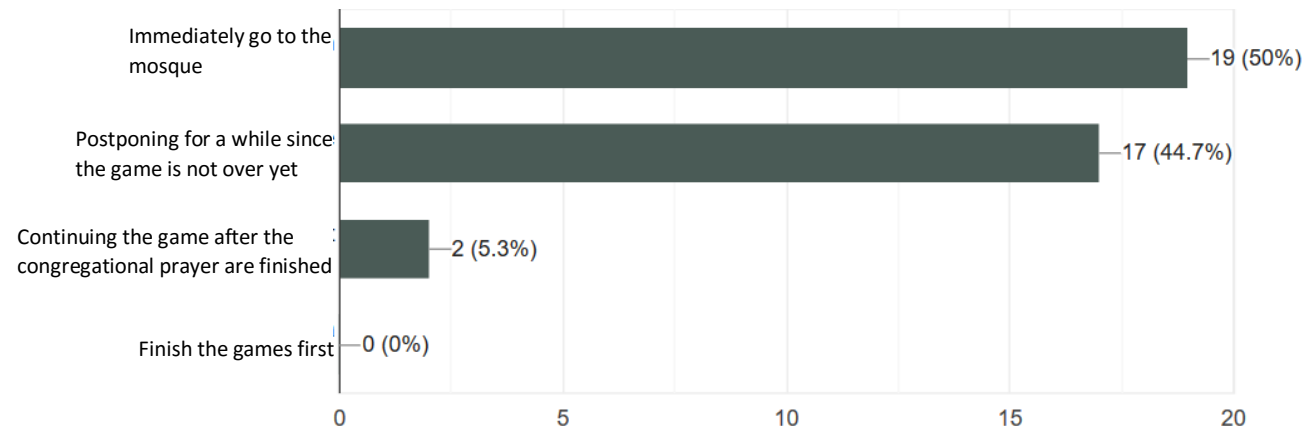

Fig. 13. The Question 13 Recapitulation Results

Fig. 13 shows that the 19 subjects at Junior High School X chose to directly go to Mosque right after listening the prayer calling (50\%). Meanwhile, only two subject chose to finish the game first instead of doing their religion responsibility (5.3\%). Fig. 14 illustrates the response of the subject regarding the influence of gadget use on their Holy Quran recitation activity.

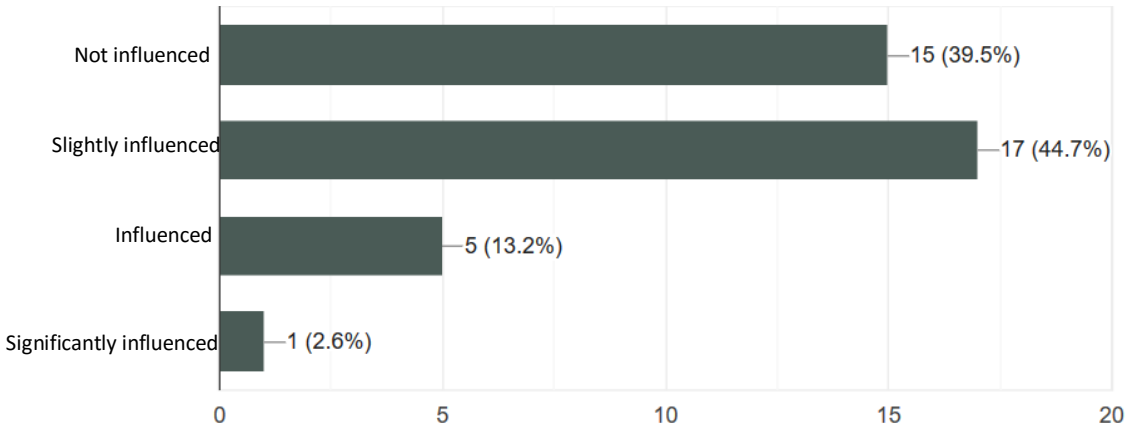

Fig. 14. The Question 14 Recapitulation Results

Based on Fig. 14, there were 17 subjects at Junior High School X who explained that the use of gadget slighlty influenced their Holy Quran recitation activity (44.7\%). Meanwhile, only one subject who explained that the use of gadget significantly influenced the Holy Quran recitation activity $(2.6 \%)$

\section{Discussions}

\subsection{The Characteristics of Gadget Use}

The findings of this research confirmed that $84.6 \%$ adolescences at Junior High School X own personal gadget (Fig 1). In addition, the adolescences who own personal gadget for more than two years was 53.8\% (Fig. 2). Internet Safety expert from Ohio, Jesse Weinberger explains that parents shouldn't buy their kids mobile phone [12]. These days, it is inevitable that smartphone is the new addictive stuff that distract child's development [13], [14]. Therefore, parents need to have careful consideration before deciding to buy their kids a mobile phone to avoid its negative impact in the near future.

According to the findings, the highest daily average use of gadgets among adolescences at Junior High School X was 1-3 hours (amounted to 51.3\%) and as much as $43.6 \%$ of them used gadget from 3-5 hours a day (Fig. 5). American Academy of Pediatrics (AAP) suggests that children 12-15 years old should maximally spent 2 hours a day to play their gadget [15]. Benger et al. and Paiva et al., explain that the duration spent by children in playing their gadgets or accessing internet is closely related to the physical and mental health [16], [17]. Other research conducted by Hepilita and Gantas; Saquib; and Muthukrishnan has confirmed that there is a significant correlation between the 
duration of accessing social media and children's sleep in pattern disorder [18]-[20]. Based on the recommendation of AAP, then the duration spent by the subjects of this research have exceeding the limit. When the adolescences of Junior High School X spent their hour intensively to interact with their gadget which exceed the duration recommended, it obstructs their mental and physical health. Thus, it requires parental and teacher guidance related to the gadget use among adolescences at Junior High School X. Not to mention, an education related to how to appropriately use gadget by school and a strict regulation imposed with relevant punishment are needed.

Then, based on the obtained findings, the subjects are commonly connected by using Wi-Fi (59\%) and it is followed by personal internet data quota as much as $51.3 \%$ and peer-tethering connection as much as $5.1 \%$ (Fig. 4). It is in line with the survey conducted by Ministry of Communication and Information of Indonesia confirming that Wi-Fi is the most widely used connection [2].

Meanwhile, the results of the recapitulation of answers about the use of internet access by the adolescences at Junior High School X are shown in Fig. 5. The social media platform that is often used by the adolescences at Junior High School $X$ is WhatsApp (Fig. 6). Data from Hootsuite mentions the highest use of social media is WhatsApp then it is followed by Facebook, Instagram, Twitter, etc. [5]. In contrast to the results of the Hootsuite survey, APJII and the Ministry of Communication and Information confirmed that Facebook and Instagram into the most visited social media [2], [4]. Based on APJII and the Ministry of Communication and Information survey data and research that has been done, social media plays an important role in the social life of the community, especially teenagers these days. It is necessary to have good time management and discipline so that the social life of adolescents with their environment is balanced [20].

\subsection{The Impact of Using Gadgets on Social Aspects}

1) Studying Concentration Aspects

Based on the data obtained from the study, it states that there is slight influence of the use of gadgets on the studying concentration among adolescences in Junior High School X (Fig. 7). This finding can be explained by the fact that the adolescences in Junior High School X have been able to manage the time between studying and using their gadgets thus they do not interfere much with the learning process. In contrast, there were eight children $(20.5 \%)$ who stated that gadgets influence the concentration of studying (Fig. 7). Research conducted [21], Mentions that the adolescences in Junior High School X who rarely use gadgets will have high achievements [21]. Whereas Hedge et al. stated that the adolescences in Junior High School X who like to use gadgets will have difficulty concentrating thereby reducing their learning achievement [22]. From these two studies there is a very close correlation between the use of gadgets and student's learning achievement in schools. It is necessary to have the role of parents and the school in supervising the use of gadgets by adolescents both at home, school, and social environment to avoid the interference of studying concentration and learning achievement.

\section{2) The Influence of Pornographic Content}

According to WHO, the age standard of adolescence is between 10-19 years old [22]. During this phase, adolescence will have a significant changing in terms of sexual attraction and motivation to the other gender [23]. The development of body parts related to sexual as well as the hormones lead to a sexual attraction among adolescences [24].

No exception for adolescences in Junior High School X, since most of them own gadgets (amounted to $84.6 \%$ ), then it is probable that the negative effects of the internet will be easily accessed by them, either intentionally or not accessing pornographic content. This was proven as many as $53.8 \%$ of the adolescences in Junior High School X who sometimes accessed pornographic content and as many as three people often accessed pornographic content (Fig. 8). It is in line with the results of a survey on the use of ICT by Research and Development Institute of The Ministry of Communication and Information which states that around 74\% of pornography becomes negative content that is often found when accessing online media [2].

The most paramount effect of pornographic content addiction is the obstruction of thinking ability that will further influence the thinking process such as memorizing and recalling the stored memory in the brain [25], [26]. The thinking process of adolescence will be obstructed and it further show a regression in thinking, processing information, and paying attention to certain task [27]. 
The findings of this study mention that sometimes a number of 22 adolescences in Junior High School X used their gadget to contact their other gender classmates $(56.4 \%)$ and nine adolescences in Junior High School X frequently contact their other gender classmates using their gadget (23.1\%) (Fig 9). The communication of adolescence between two different genders is inevitable. However since the influence of pornographic content these days is unavoidable, the relationship of different gender among adolescence will have greater negative impact such as the possibility of promiscuity [6], [28]. The role of religion teacher in this context is vital to give comprehensive guidance based on religious values as an attempt to prevent the negative impact [29]. To avoid any negative impact from the relationship of different genders such as promiscuity and the negative effect of pornographic content, it is important for every individual to hold on the word of the Almighty Allah 此 as follows:

'Tell the believing men to reduce [some] of their vision and guard their private parts. That is purer for them. Indeed, Allah is Acquainted with what they do." [QS.An-Nur: 30]

\section{3) Social Relation Aspect}

The results of this study indicate that as many as $61.5 \%$ of teenagers in SMP X felt undisturbed when using gadget and their parents or friends ask for help (Fig 10). This shows that most of the adolescences in Junior High School X have good social interactions and sympathy towards others [30]. Furthermore, good communication is indicated by empathy [31], [32]. Meanwhile, there were two adolescences in Junior High School X who were very disturbed. This further shows a symptom of addiction and dependence with gadget. Alifiani said that changes in communication patterns in adolescents were influenced by the use of gadgets and tended to ignore the presence of people around when operating gadgets [32]. An individual who considers gadget as his/her vital stuff and ignores his/her surrounding environment is a symptom of antisocial behaviour [33]. When an individual has less interaction with his/her surrounding environment, he or she will be difficult to have social life.

This research also confirmed that most of the adolescences in Junior High School X could not stay away from their gadget while doing another activity (as much as 50\%) (Fig. 11). In addition, some of them tended to choose to play with their gadget instead of playing with their friends (23.7\%) (Fig. 12). These findings further affirm that they tend to be addicted to gadget. This is in line with the research conducted by Hasanah which conclude that the use of gadget among the children influences the physical and psychological aspects for instance avoiding social interaction with their surrounding environment, having relatively bad relationship with the parents, easily feel bored, and having less attention and concentration when doing certain task in the real life [34].

\section{4) Religious Aspect}

The other negative impact from the use of gadget is also caused by the online/offline games [35]. The findings of this research confirm that some of the adolescences in Junior High School X (50\%) directly put down their gadget the moment they heard the prayer calling. Meanwhile several $44.7 \%$ subject postponed their responsibility and continued to play. Then, a few 5.3\% of the subjects remained playing and did not perform their obligation to pray (Fig. 13). Based on this finding, it is assumed that the most subjects do not have a tendency of being gadget addict. Only two subjects that are being a gadget addict since they completely postponed their obligation due to mobile game. This is in line with Lee et al. which explain that a gadget addict individual has some issues regarding his/her mental health, one of them is bad attention to the surrounding. When an individual having a relatively bad attention to the surrounding, he/she will have insignificant sensitivity, as a result, when the prayer calling is echoed, he/she ignores it.

Besides, this research affirms that the intense use of gadget by the adolescences negatively influences on the Holy Quran recitation they progress (15.8\%) (Fig. 4). This is due to the degradation of brain function; the brain will have limited function when working. Rapid information spreading through media that is received continuously influences the ability to have good concentration and memorization [37], [38]. It is further concluded that the six subjects in this research who answered that the gadget significantly influence their concentration have an intense use of gadget (more than two hours a day). Consequently, it significantly influences the quality of learning and concentration when reciting the Holy Quran. 
Excessive use of gadgets is also not appropriate in the Islamic view, because it has negative consequences for the religious life of adolescents as described above. In the Qur'an and the Hadith of the Prophet Muhammad is mentioned:

"..... do not probibit the good things which Allah has made lawful to you and do not transgress. Indeed, Allah does not like transgressors" [QS. Al Ma'idab: 87$]$

"Among the goodness of Islam is to leave something that is not useful" [Hadith by Tirmidzi no. 2317, Ibnu Majah no. 3976$]$

\section{Conclusion}

The conclusions of this study are as follows. First, the characteristics of the use of gadgets by adolescences in Junior High School X is most of them have personal gadgets more than two years; the duration of using gadget is between 1-5 hours/day; most of them use Wi-Fi to connect to the internet; most of them use internet for accessing social media; and WhatsApp is the most used application for social media.

Second, the impact of the use of gadgets on the social aspects of adolescences in Junior High School $\mathrm{X}$ is as follows. 1) Effects of pornography; most of them have accessed pornographic content, even three people often access pornographic content. 2) Most of the adolescences in Junior High School X have good and balanced social interaction with their environment, but there are two people who have symptoms of gadget addiction. 3) Most of the adolescences in Junior High School $\mathrm{X}$ are likely not affected by the presence of gadgets in terms of studying concentration. 4) Most of the adolescences in Junior High School X have good spiritual aspect, it is proven by the answer provided by them explaining that they immediately pray when they are hearing the prayer call, and most of them have insignificant effect on Holy Quran recitation. Even so, there are a small number of adolescences in Junior High School $\mathrm{X}$ requiring the attention and guidance of parents and teachers because of the possibility of addiction to gadgets that can affect their mental health and social-spiritual life.

\section{References}

[1] A. K. Sherlyanita and N. A. Rakhmawati, "Pengaruh dan pola aktivitas penggunaan internet serta media sosial pada siswa SMPN 52 Surabaya," J. Inf. Syst. Eng. Bus. Intell., vol. 2, no. 1, pp. 17-22, 2016.

[2] Kementerian Komunikasi dan Informatika, "Buku saku penggunaan teknologi informasi dan komunikasi serta implikasinya terhadap aspek sosial dan budaya masyarakat tahun 2018." Badan Penelitian dan Pengembangan SDM, Jakarta, 2018.

[3] I. Lestari, A. W. Riana, and B. M. Taftazani, "Pengaruh gadget pada interaksi sosial dalam keluarga," Pros. Penelit. dan Pengabdi. Kpd. Masy., vol. 2, no. 2, pp. 147-300, 2015.

[4] APJII, "Laporan survei: Penetrasi dan profil perilaku pengguna internet Indonesia." Jakarta, 2019.

[5] H. Hootsuite, "Digital 2019: Indonesia." 2019.

[6] H. Indrijati, "Penggunaan internet dan perilaku seksual pranikah remaja," Pros. Temu Ilm. Nas. X Ikat. Psikol. Perkemb. Indones., vol. 1, 2017.

[7] E. A. Makarova and E. L. Makarova, "Aggressive Behavior in Online Games and Cybervictimization of Teenagers and Adolescents," Int. Electron. J. Elem. Educ., vol. 12, no. 2, pp. 157-165, 2019.

[8] L. Wartberg, L. Kriston, K. Kegel, and R. Thomasius, "Adaptation and psychometric evaluation of the Young Diagnostic Questionnaire (YDQ) for parental assessment of adolescent problematic Internet use," J. Behav. Addict., vol. 5, no. 2, pp. 311-317, 2016.

[9] S. Al Majali, "The digital world for children and its relationship with personality disorders: Exploring emerging technologies," Int. J. Emerg. Technol. Learn., vol. 15, no. 01, pp. 213-221, 2020.

[10] K. M. Master, C. P. Kaur, A. Narasimhan, N. Mizrab, M. Ali, and R. B. Shaik, "Impact of electronic gadgets on psychological behavior of middle school children in UAE," Uni Emirates Arab. Gulf Med. J., vol. 5, no. S2, pp. S54-S60, 2016. 
[11] J. W. Creswell and J. D. Creswell, Research design: Qualitative, quantitative, and mixed methods approaches. Sage publications, 2017.

[12] I. D. A. D. Putra and F. Rahmawati, "Educating smartphone use in early childhood, through designing parenting books illustrations," in 6th Bandung Creative Movement 2019, 2019, pp. 34-38.

[13] A. A. H. Putri and H. Khairunnisa, "The relationship of family function and social media addiction among adolescents," 2019.

[14] H. A. Rosyid, E. Fajariani, H. Adhilaga, and A. Amalia, "The online game addiction psychology and interpersonal relationship of the engineering students," Bull. Soc. Informatics Theory Appl., vol. 3, no. 2, pp. 75-79, 2019.

[15] J. Falbe, B. Rosner, W. C. Willett, K. R. Sonneville, F. B. Hu, and A. E. Field, "Adiposity and different types of screen time," Pediatrics, vol. 132, no. 6, pp. e1497-e1505, 2013.

[16] R. E. Bélanger, C. Akre, A. Berchtold, and P.-A. Michaud, "A U-shaped association between intensity of Internet use and adolescent health," Pediatrics, vol. 127, no. 2, pp. e330-e335, 2011.

[17] T. Paiva, T. Gaspar, and M. G. Matos, "Sleep deprivation, sleep stealers and risk behaviors in Portuguese adolescents-A cross-cultural comparison," MOJ Public Heal., vol. 3, no. 1, p. 49, 2015.

[18] Y. Hepilita and A. A. Gantas, "Hubungan durasi penggunaan media sosial dengan gangguan pola tidur pada anak usia 12 sampai 14 tahun di SMP negeri 1 Langke Rembong," Wawasan Kesehat., vol. 3, no. 2, pp. 78-87, 2018.

[19] J. Saquib, "Social ecological model as a framework for understanding screen time and sedentary behavior among Arab adolescents," Int. J. Health Sci. (Qassim)., vol. 12, no. 3, p. 1, 2018.

[20] J. Muthukrishnan, "Gadgets, sleep and obesity," Praxis (Bern. 1994)., vol. 1, no. 1, 2018.

[21] B. Manumpil, A. Y. Ismanto, and F. Onibala, "Hubungan penggunaan gadget dengan tingkat prestasi siswa di SMA Negeri 9 Manado," J. Keperawatan, vol. 3, no. 2, pp. 1-6, 2015.

[22] P. L. P. Rori, "Pengaruh penggunaan minuman keras pada kehidupan remaja di desa Kali kecamatan Pineleng kabupaten Minahasa," HOLISTIK, J. Soc. Cult., vol. 8, no. 17, pp. 1-12, 2016.

[23] D. Imawati and M. T. Sari, "Studi kasus kecanduan pornografi pada remaja," Motiv. J. Psikol., vol. 1, no. 2, pp. 56-62, 2019.

[24] R. Bhattacharyya, "Addiction to modern gadgets and technologies across generations," East. $J$. Psychiatry, vol. 18, no. 2, 2017.

[25] R. de Alarcón, J. I. de la Iglesia, N. M. Casado, and A. L. Montejo, "Online porn addiction: What we know and what we don't—A systematic review," J. Clin. Med., vol. 8, no. 1, p. 91, 2019.

[26] M. F. A. Saputra, S. A. Siregar, and Z. N. Izdihar, "Social effects of digital pornography," Bull. Soc. Informatics Theory Appl., vol. 1, no. 2, pp. 79-85, 2017.

[27] A. M. Rajab et al., "Gaming addiction and perceived stress among Saudi adolescents," Addict. Behav. Reports, p. 100261, 2020.

[28] L. K. Rizki and R. Amalia, "Analysis of factors affecting sexual behavior in adolescents in the Porong health center work area," J. Heal. Sci., vol. 12, no. 02, pp. 36-44, 2019.

[29] N. L. Al-adawy, "Peran guru pendidikan agama Islam dalam mencegah perilaku seks bebas di SMPN 2 Ngantang Malang." Universitas Islam Negeri Maulana Malik Ibrahim, 2019.

[30] S. W. Sarwono, Psikologi remaja, Revisi. Jakarta: Rajawali Press, 2011.

[31] A. Abu and S. Munawar, Psikologi perkembangan. Jkarta: Rineka Cipta, 2005.

[32] H. Alifiani, N. Nurhayati, and Y. Ningsih, "Analisis penggunaan gadget terhadap pola komunikasi keluarga," Faletehan Heal. J., vol. 6, no. 2, pp. 51-55, 2019.

[33] J. A. Heerde, A. Curtis, J. A. Bailey, R. Smith, S. A. Hemphill, and J. W. Toumbourou, "Reciprocal associations between early adolescent antisocial behavior and depressive symptoms: A longitudinal study in Victoria, Australia and Washington State, United States," J. Crim. Justice, vol. 62, no. MayJune, pp. 74-86, 2019. 
[34] M. Hasanah, "Pengaruh gadget terhadap kesehatan mental anak," Indones. J. Islam. Early Child. Educ., vol. 2, no. 2, pp. 207-214, 2017.

[35] N. Saquib et al., "Video game addiction and psychological distress among expatriate adolescents in Saudi Arabia," Addict. Behav. reports, vol. 6, pp. 112-117, 2017.

[36] S. Setianingsih, "Dampak penggunaan gadget pada anak usia prasekolah dapat meningkatan resiko gangguan pemusatan perhatian dan hiperaktivitas," Gaster, vol. 16, no. 2, pp. 191-205, 2018.

[37] S. A. Murtaza, "Digital heroin the impact of digital gadgets on developing minds an empirical study on growing children of Lahore," in International Conference on Management, Business \& Technology (ICMBT), 2017, pp. 303-309. 